\title{
Pengaruh Level Protein dan Suplementasi Ekstrak Daun Katuk (Sauropus androgynus) terhadap Kualitas Karkas Broiler
}

\author{
Effects of Protein and Katuk (Sauropus androgynus) Leaves Extract Supplementation \\ Levels on Carcass Qualities of Broilers
}

Siti Qotimah, Urip Santoso, Edi Soetrisno

Jurusan Peternakan, Fakultas Pertanian, Universitas Bengkulu

Jalan Raya W. R Supratman, Kandang Limun, Bengkulu 38371 A

Email : siti_qotimah@yahoo.com

\begin{abstract}
The present experiment was conducted to evaluate effects of protein and katuk (Sauropus androgynus) leaves extract supplementation levels on carcass qualities of broilers. Seventy two broilers aged 21 days of age were distributed to 6 treatment groups of 3 replicates with 4 birds each. Factorial completely randomized experimental design (2x3) was used in the present study. There were two levels of katuk leaves extract $(4,5 \mathrm{~g} / \mathrm{kg}$ and $9 \mathrm{~g} / \mathrm{kg})$ and three levels of protein $(19 \%, 17 \%$, and 15\%). Variables observed were carcass color, carcass weight, meat bone ratio, cooking loss, and drip loss. The results showed that supplementation level of katuk leaves extract significantly affected carcass color $(\mathrm{P}<0.05)$, but it had no effect $(\mathrm{P}>0,05)$ on carcass weight, meat bone ratio, cooking loss and drip loss. Level of protein had no effect $(\mathrm{P}>0.05)$ on carcass color, cooking loss and drip loss, but it was significant effect on carcass weight $(\mathrm{P}<0.05)$ and meat bone ratio $(\mathrm{P}<0.01)$. In conclusion, supplementation of katuk leaves extract on $9 \mathrm{~g} / \mathrm{kg}$ improved carcass color. The $15 \%$ protein containing diet reduced carcass weight and meat bone ratio. No interaction was found between protein level and katuk leaves extract supplementation levels on improving carcass qualities.
\end{abstract}

Key word : carcass qualities, Katuk (Sauropus androgynus) leaves extract, protein

\section{ABSTRAK}

Penelitian ini bertujuan untuk mengevaluasi pengaruh level protein dan suplementasi ekstrak daun katuk (Sauropus androgynus) terhadap kualitas karkas broiler. Sebanyak 72 ekor broiler umur 21 hari dikelompokkan menjadi 6 kelompok perlakuan dengan 3 ulangan, masing-masing ulangan berisi 4 ekor broiler. Rancangan acak lengkap dengan 2 faktor ( $2 \times 3$ ) digunakan dalam penelitian ini, yaitu 2 level suplementasi ekstrak daun katuk (4,5 $\mathrm{g} / \mathrm{kg}$ dan $9 \mathrm{~g} / \mathrm{kg}$ ) dan 3 level protein $(19 \%, 17 \%$ dan $15 \%)$. Variabel yang diamati meliputi warna karkas, berat karkas, meat bone ratio, cooking loss dan drip loss. Hasil penelitian menunjukkan bahwa suplementasi level ekstrak daun katuk berpengaruh nyata terhadap warna karkas $(\mathrm{P}<0,05)$, tetapi berpengaruh tidak nyata $(\mathrm{P}>0,05)$ terhadap persentase berat karkas, meat bone ratio, cooking loss dan drip loss. Hasil penelitian menunjukkan bahwa level protein berpengaruh tidak nyata $(\mathrm{P}>0,05)$ terhadap warna karkas, cooking loss dan drip loss, tetapi berpengaruh nyata terhadap persentase berat karkas $(\mathrm{P}<0,05)$ dan berpengaruh sangat nyata $(\mathrm{P}<0,01)$ terhadap meat bone ratio. Kesimpulan dari penelitian ini adalah bahwa suplementasi ekstrak daun katuk pada level $9 \mathrm{~g} / \mathrm{kg}$ meningkatkan warna karkas. Pemberian pakan berprotein $15 \%$ menurunkan persentase karkas dan meat bone ratio. Pemberian level protein dan suplementasi ekstrak daun katuk tidak menunjukkan adanya interaksi untuk meningkatkan kualitas karkas broiler.

Kata kunci : ekstrak daun katuk (Sauropus androgynus), protein, kualitas karkas

\section{PENDAHULUAN}

Pakan sangat dibutuhkan sebagai penunjang kebutuhan hidup ternak. Ahli nutrisi unggas belakangan ini banyak tertarik untuk menurunkan kadar protein dalam pakan broiler dengan alasan bahwa:
1) pakan berprotein rendah akan menurunkan biaya pakan karena protein merupakan zat nutrisi termahal dalam pakan broiler; 2) pakan berprotein rendah akan menurunkan tingkat pencemaran akibat ekskresi nitrogen yang berlebihan (El-Hakim et al., 2009). Memberikan 
pakan dengan level protein yang berbeda telah dilakukan dalam beberapa penelitian dengan tujuan untuk mengevaluasi pengaruh level paling rendah terhadap performans maupun kualitas karkas broiler. Namun pemberian level protein yang rendah dalam pakan dapat menimbulkan beberapa kerugian yaitu menurunkan performans hasil karkas (Bregendahl et al., 2002). Swennen et al. (2007) menemukan bahwa pemberian pakan berprotein rendah menurunkan kadar protein pada broiler.

Pemberian pakan dengan level protein rendah meningkatkan deposisi lemak pada berbagai bagian tubuh broiler dan meningkatkan kadar lemak dalam daging dan karkas (Pesti, 2009). Peningkatan deposisi lemak ini dapat menyebabkan substrat untuk sintesis protein menurun, sehingga kadar protein dalam daging pun menurun. Menurunnya kadar protein dalam tubuh broiler akan berpengaruh pada meningkatnya cooking loss dan drip loss. Pakan dengan level protein rendah diduga menurunkan ketersediaan zat-zat gizi sehingga berpengaruh terhadap kualitas karkas dan daging broiler seperti warna karkas, persentase berat karkas, meat bone ratio, cooking loss dan drip loss.

Katuk (Sauropus androgynus) merupakan tanaman obat-obatan tradisionil yang mempunyai zat gizi tinggi, senyawa antibakteri, antioksidan dan mengandung beta karoten yang tinggi sebagai zat aktif warna karkas dan meningkatkan kadar vitamin A dalam karkas broiler. Hulshofet al. (1997) melaporkan bahwa diantara sayuran dan buah-buahan yang diteliti di Indonesia, daun katuk mengandung $\beta$ karoten tertinggi dengan jumlah all-trans$\alpha$-carotena $1335 \pm 878 \mu / 100 \mathrm{~g}$, all-trans- $\beta$ carotena $10010 \pm 2189 \mu / 100 \mathrm{~g}, \quad$ cis- $\beta$ carotena $1312 \pm 349 \mu / 100 g$. Kandungan dalam katuk adalah protein, lemak, kalsium, fosfat, besi, vitamin A,B,C, steroid, flavonoid, dan polifenol. Azis dan Muktiningsih (2006) menyatakan bahwa kandungan zat makanan katuk per 100 gram adalah kalori $59 \mathrm{kal}$, protein $6,4 \mathrm{~g}$, lemak $1 \mathrm{~g}$, hidrat arang 9,9 g, serat 1,5 g, abu 1,7 g, kalsium $233 \mathrm{mg}$, phosphor 98 $\mathrm{mg}$, besi 3,5 mg, karoten $10.020 \mu \mathrm{g}$, vitamin B dan C $164 \mathrm{mg}$, dan air $81 \mathrm{~g}$. Katuk merupakan sayuran yang bergizi dengan kandungan protein sekitar 33,68\% per 100 gram katuk kering (Azis dan Muktiningsih, 2006).

Berdasarkan uraian tersebut, maka diduga katuk mampu memperbaiki kualitas pakan dengan berbagai level protein dengan harapan kualitas karkas yang dihasilkan tetap baik.

Senyawa dalam daun katuk yang berperan dalam peningkatan penampilan kualitas karkas diduga antara lain monomethyl succinate, cis-2-methyl cyclopentanol acetate (ester), benzoic acid, phenyl malonic acid (carboxylic acid), 2pyrrolidinon, methyl pyroglutamate (alkaloid) (Agustal et al., 1997). Suprayogi (2000) menemukan adanya lima senyawa aktif dalam daun katuk yang mempunyai peran penting dalam metabolisme jaringan. Lima senyawa kelompok dari asam lemak tak jenuh seperti octadecanoic acids; 9eicosyne; 5,8,11-heptadecatrienoic acid methyl ester; 9,12,15-octadecatrienoic acid ethyl ester; dan 11,14,17eicosatrienoic acid methyl ester. Satu 
senyawa steroid, yaitu androstan-17-one, 3-ethyl-3-hydroxy-5 alpha (steroid). Senyawa lain, yaitu 3,4-dimethyl-2oxocyclopent-3-enylacetic acid.

Santoso (2001) menemukan bahwa pemberian ekstrak daun katuk (EDK) sebanyak $18 \mathrm{~g} / \mathrm{kg}$ ransum mampu meningkatkan kualitas karkas ayam pedaging yang ditandai dengan lebih rendahnya cooking loss, meningkatnya rasa daging, dan menurunkan bau amis daging serta menurunnya lemak abdomen. Santoso (2001) menemukan bahwa pemberian ekstrak daun katuk sebesar $18 \mathrm{~g} / \mathrm{kg}$ ransum menghasilkan warna dada yang lebih pucat.

Santoso et al. (2001) juga menemukan bahwa pemberian ekstrak daun katuk sebanyak 4,5 g/l air minum meningkatkan warna kuning karkas. Lebih kuningnya warna karkas diduga oleh zat pewarna yaitu $\beta$-karoten. Telah diketahui bahwa daun katuk kaya akan zat pewarna tersebut (Anonimus, 1992).

Santoso et al. (2002) menemukan bahwa pemberian ekstrak daun katuk melalui kombinasi cara pemberian yaitu 4,5 g ekstrak daun katuk/kg ransum plus 2,25 g ekstrak daun katuk/l air minum dapat meningkatkan warna karkas.

Pada taraf 9\% penambahan daun katuk dapat meningkatkan kualitas telur dan karkas (Subekti, 2003). Saragih (2005) melaporkan bahwa penambahan tepung daun katuk sebesar $15 \%$ pada ransum ayam petelur dapat meningkatkan kualitas telur, konsentrasi karoten dan vitamin A dalam telur, dan mampu menurunkan kolesterol dalam kuning telur, hati dan karkas.
Berdasarkan uraian di atas, maka perlu dilakukan penelitian tentang pengaruh level protein dan suplementasi ekstrak daun katuk (Sauropus androgynus) untuk mengetahui interaksinya terhadap kualitas karkas broiler.

Penelitian ini bertujuan untuk mengevaluasi pengaruh level protein dan level suplementasi ekstak daun katuk (Sauropus androgynus) terhadap kualitas karkas broiler.

\section{MATERI DAN METODE}

Penelitian ini dilaksanakan pada tanggal 28 April 2013 sampai tanggal 19 Mei 2013 di Commercial Zone and Animal Laboratory (CZAL) Jurusan Peternakan Fakultas Pertanian Universitas Bengkulu. Dua ratus ekor broiler umur satu hari dipelihara dalam kandang litter. Pada umur 21 hari, semua broiler ditimbang dan diseleksi. Sebanyak 72 ekor broiler dikelompokkan menjadi 6 kelompok perlakuan dengan 3 ulangan, masingmasing ulangan berisi 4 ekor broiler. Rancangan acak lengkap dengan 2 faktor digunakan dalampenelitian ini, yaitu 2 level suplementasi ekstrak daun katuk/EDK $(4,5 \mathrm{~g} / \mathrm{kg}$ dan $9 \mathrm{~g} / \mathrm{kg})$ dan 3 level protein (19\%, 17\% dan 15\%).

Adapun ke enam kelompok perlakuan tersebut sebagai berikut:

$$
\begin{aligned}
& \text { P1K1 }: 19 \% \text { protein }+4,5 \mathrm{~g} / \mathrm{kg} \text { EDK } \\
& \mathrm{P} 2 \mathrm{~K} 1: 17 \% \text { protein }+4,5 \mathrm{~g} / \mathrm{kg} \text { EDK } \\
& \mathrm{P} 3 \mathrm{~K} 1: 15 \% \text { protein }+4,5 \mathrm{~g} / \mathrm{kg} \text { EDK } \\
& \mathrm{P} 1 \mathrm{~K} 2: 19 \% \text { protein }+9 \mathrm{~g} / \mathrm{kg} \mathrm{EDK} \\
& \mathrm{P} 2 \mathrm{~K} 2: 17 \% \text { protein }+9 \mathrm{~g} / \mathrm{kg} \text { EDK } \\
& \mathrm{P} 3 \mathrm{~K} 2: 15 \% \text { protein }+9 \mathrm{~g} / \mathrm{kg} \text { EDK }
\end{aligned}
$$


Komposisi ransum basal yang pada Tabel 1 berikut. digunakan dalam penelitian ini disajikan

Tabel 1. Susunan ransum basal penelitian yang digunakan tiap perlakuan

\begin{tabular}{|c|c|c|c|c|c|c|}
\hline Bahan Ransum (\%) & $\mathrm{P} 1 \mathrm{~K} 1$ & $\mathrm{P} 2 \mathrm{~K} 1$ & P3K1 & $\mathrm{P} 1 \mathrm{~K} 2$ & $\mathrm{P} 2 \mathrm{~K} 2$ & $\mathrm{P} 3 \mathrm{~K} 2$ \\
\hline Jagung Kuning & 57,0 & 60,69 & 59,44 & 57,0 & 60,69 & 59,44 \\
\hline Dedak & 5,0 & 8,82 & 17,57 & 5,0 & 8,82 & 17,57 \\
\hline Konsentrat Broiler & 34,2 & 26,69 & 19,19 & 34,2 & 26,69 & 19,19 \\
\hline Mineral mixture & 1,7 & 1,7 & 1,7 & 1,7 & 1,7 & 1,7 \\
\hline Garam Dapur & 0,1 & 0,1 & 0,1 & 0,1 & 0,1 & 0,1 \\
\hline Top Mix & 0,5 & 0,5 & 0,5 & 0,5 & 0,5 & 0,5 \\
\hline Minyak & 1,5 & 1,5 & 1,5 & 1,5 & 1,5 & 1,5 \\
\hline Ekstrak Daun Katuk (EDK) & 4,5 & 4,5 & 4,5 & 9,0 & 9,0 & 9,0 \\
\hline \multicolumn{7}{|l|}{ Kandungan Nutrien : } \\
\hline Protein $\%$ & 19,35 & 17,13 & 15,06 & 19,35 & 17,13 & 15,06 \\
\hline $\mathrm{ME}(\mathrm{Kkal} / \mathrm{kg})$ & 3155,58 & 3150,18 & 3102,29 & 3155,58 & 3150,18 & 3102,29 \\
\hline $\mathrm{Ca}$ & 1,51 & 1,31 & 1,11 & 1,51 & 1,31 & 1,11 \\
\hline $\mathrm{P}$ & 0,86 & 0,81 & 0,81 & 0,86 & 0,81 & 0,81 \\
\hline
\end{tabular}

Drip loss diperoleh dengan cara mengurangi berat daging sebelum dimasukkan freezer dengan berat daging setelahproses thawing yang sebelumnya telah masuk freezer selama 3 hari. Proses thawing dilakukan dengan menggantung daging hingga tidak ada lagi tetesan air.

\section{HASIL DAN PEMBAHASAN}

Pengaruh level protein terhadap kualitas karkas broiler tertera pada Tabel 2. Hasil analisis varian menunjukkan bahwa level protein berpengaruh tidak nyata terhadap warna karkas,cooking loss dan drip loss $(\mathrm{P}>0,05)$, tetapi berpengaruh nyata terhadap persentase berat karkas $(\mathrm{P}<0,05)$, dan berpengaruh sangat nyata terhadap meat bone ratio bagian dada dan paha $(\mathrm{P}<0,01)$. Pemberian pada level protein $15 \%$ menurunkan berat karkas dan meat bone ratio bagian dada dan paha karena rataan jumlah konsumsi protein pada level protein $15 \%$ lebih rendah yaitu 501,4 g/ekor jika dibandingkan konsumsi protein pada level protein 17\% yaitu 612,9 g/ekor dan konsumsi protein pada level protein 19\% yaitu 703,4 g/ekor. Konsumsi protein yang rendah mempengaruhi berat karkas yang dihasilkan karena protein merupakan struktur yang sangat penting untuk membentuk jaringan-jaringan lunak di dalam tubuh hewan seperti urat daging, tenunan pengikat, kolagen, kulit, kuku dan pada ayam untuk pertumbuhan bulu, kuku, dan bagian tanduk serta paruh (Wahju, 2004). Terhambatnya pertumbuhan jaringan maka akan berpengaruh terhadap karkas yang dihasilkan. Hal ini juga dapat menyebabkan perbandingan daging dengan tulang lebih kecil.

Hasil penelitian ini sesuai dengan penelitian Bregendahl et al. (2002) bahwa pemberian pakan berprotein rendah dapat menurunkan hasil karkas. Tetapi hasil penelitian ini berlawanan dengan hasil penelitian Farahdiba (2011) yang menemukan bahwa aras protein $15 \%$ berpengaruh tidak nyata terhadap berat karkas. 
Tabel 2. Pengaruh level protein terhadap kualitas karkas broiler

\begin{tabular}{|c|c|c|c|c|}
\hline Variabel & $19 \%$ & $17 \%$ & $15 \%$ & $\mathrm{P}$ \\
\hline Warna karkas & $102,45 \pm 0,78$ & $102,1 \pm 0$ & $102,6 \pm 0,28$ & ns \\
\hline Persentase berat karkas $(\%)$ & $68,66 \pm 1,10^{\mathrm{a}}$ & $68,87 \pm 2,47^{\mathrm{a}}$ & $66,18 \pm 0,14^{\mathrm{b}}$ & $\mathrm{P}<0,05$ \\
\hline Meat bone ratio & $4,16 \pm 0,50^{\mathrm{ab}}$ & $4,35 \pm 0,49^{\mathrm{a}}$ & $2,95 \pm 0,64^{\mathrm{b}}$ & $\mathrm{P}<0,01$ \\
\hline Cooking loss $(\%)$ & $37,44 \pm 0,23$ & $37,10 \pm 1,56$ & $36,35 \pm 1,48$ & ns \\
\hline Drip loss $(\%)$ & $8,18 \pm 1,24$ & $8,75 \pm 2,19$ & $7,85 \pm 0,21$ & ns \\
\hline
\end{tabular}

Pengaruh suplementasi ekstrak daun katuk terhadap kualitas karkas broiler tertera pada Tabel 3. Hasil penelitian menunjukkan bahwa suplementasi ekstrak daun katuk memberikan pengaruh nyata terhadap warna karkas $(\mathrm{P}<0,05)$, tetapi berpengaruh tidak nyata terhadap persentase berat karkas, meat bone ratio, cooking loss, dan drip loss. Suplementasi ekstrak daun katuk pada level $9 \mathrm{~g} / \mathrm{kg}$ secara nyata meningkatkan warna karkas $(\mathrm{P}<0,05)$ dibandingkan dengan suplementasi pada level 4,5g/kg. Suplementasi level $9 \mathrm{~g} / \mathrm{kg}$ menghasilkan warna karkas yang lebih kuning. Hal ini karena pada ekstrak daun katuk kaya akan $\beta$ karoten, kandungan karoten katuk per 100 gram adalah 10.020 $\mu \mathrm{g}$ (Azis dan Muktiningsih, 2006). Zat tersebut merupakan zat pemberi warna pada karkas. Santoso et al. (2001) dan Santoso et al. (2002) menemukan bahwa pemberian EDK sebanyak 4,5 g/l air minum meningkatkan warna kuning karkas.

Tabel 3. Pengaruh suplementasi ekstrak daun katuk terhadap kualitas karkas broiler

\begin{tabular}{lccc}
\hline \multicolumn{1}{c}{ Variabel } & \multicolumn{1}{c}{$4,5 \mathrm{~g} / \mathrm{kg}$} & $9 \mathrm{~g} / \mathrm{kg}$ & $\mathrm{P}$ \\
\hline Warna karkas & $102,13 \pm 0,25^{\mathrm{b}}$ & $102,63 \pm 0,47^{\mathrm{a}}$ & $\mathrm{P}<0,05$ \\
Persentase berat karkas (\%) & $68,71 \pm 2,35$ & $67,09 \pm 0,80$ & $\mathrm{~ns}$ \\
Meat bone ratio & $3,97 \pm 0,67$ & $3,67 \pm 1,04$ & $\mathrm{~ns}$ \\
Cooking loss (\%) & $36,30 \pm 1,18$ & $37,63 \pm 0,50$ & $\mathrm{~ns}$ \\
Drip loss (\%) & $7,50 \pm 0,44$ & $9,02 \pm 1,30$ & $\mathrm{~ns}$ \\
\hline K
\end{tabular}

Keterangan : superskrip yang berbeda pada baris yang sama menunjukkan berbeda nyata $(\mathrm{P}<0,05)$, ns $=$ non significant

Santoso et al. (2002) menemukan bahwa pemberian ekstrak daun katuk (EDK) berpengaruh tidak nyata terhadap berat karkas dan persentase karkas. Santoso et al. (2002) menemukan bahwa pemberian ekstrak daun katuk dengan berbagai cara pemberian tidak berpengaruh terhadap nisbah daging-tulang dan memberikan perbedaan yang tidak nyata $(\mathrm{P}>0,05)$ terhadap cooking loss.

Hasil penelitian menunjukkan bahwa tidak terdapat interaksi antara level protein dan suplementasi ekstrak daun katuk terhadap kualitas karkas (Tabel 4). Ini menunjukkan bahwa protein yang disuplementasi ekstrak daun katuk tidak mampu meningkatkan kualitas karkas.

Tabel 4. Pengaruh level protein dan suplementasi ekstrak daun katuk terhadap kualitas karkas broiler

\begin{tabular}{|c|c|c|c|c|c|c|}
\hline \multirow[t]{2}{*}{ Variabel } & \multicolumn{2}{|c|}{$19 \%$ protein } & \multicolumn{2}{|c|}{$17 \%$ protein } & \multicolumn{2}{|c|}{$15 \%$ protein } \\
\hline & $4,5 \mathrm{~g} / \mathrm{kg}$ & $9 \mathrm{~g} / \mathrm{kg}$ & $4,5 \mathrm{~g} / \mathrm{kg}$ & $9 \mathrm{~g} / \mathrm{kg}$ & $4,5 \mathrm{~g} / \mathrm{kg}$ & $9 \mathrm{~g} / \mathrm{kg}$ \\
\hline Warna karkas & $101,9 \pm 0,63$ & $103,0 \pm 0,41$ & $102,1 \pm 0,25$ & $102,1 \pm 0,85$ & $102,4 \pm 0,48$ & $102,8 \pm 0,50$ \\
\hline $\begin{array}{l}\text { Persentase } \\
\text { berat karkas }(\%)\end{array}$ & $69,43 \pm 3,16$ & $67,88 \pm 3,16$ & $70,61 \pm 0,98$ & $67,12 \pm 1,48$ & $66,08 \pm 1,98$ & $66,28 \pm 1,27$ \\
\hline Meat bone ratio & $3,8 \pm 1,27$ & $4,51 \pm 0,68$ & $4,7 \pm 0,65$ & $4,0 \pm 0,88$ & $3,4 \pm 1,04$ & $2,5 \pm 0,47$ \\
\hline Cooking loss $(\%)$ & $37,6 \pm 4,22$ & $37,28 \pm 6,06$ & $36,0 \pm 2,70$ & $38,2 \pm 3,85$ & $35,3 \pm 3,36$ & $37,4 \pm 4,40$ \\
\hline Drip loss $(\%)$ & $7,3 \pm 4,37$ & $9,06 \pm 5,67$ & $7,2 \pm 2,84$ & $10,8 \pm 6,93$ & $8,0 \pm 3,15$ & $7,7 \pm 6,08$ \\
\hline
\end{tabular}

Keterangan: Baris yang tidak memiliki superskrip menunjukkan berbeda tidak nyata $(\mathrm{P}>0,05)$. 


\section{SIMPULAN}

Tidak terdapat interaksi antara level protein dan suplementasi ekstrak daun katuk untuk meningkatkan kualitas karkas broiler. Suplementasi ekstrak daun katuk pada level $9 \mathrm{~g} / \mathrm{kg}$ meningkatkan warna karkas menjadi lebih kuning dan pemberian pakan berprotein $15 \%$ menurunkan persentase berat karkas dan meat bone ratio bagian dada dan paha. Namun level protein pakan dapat diturunkan dari $19 \%$ menjadi $17 \%$.

\section{DAFTAR PUSTAKA}

Agustal, A., M. Harapini dan Chairul. 1997. Analisis kandungan kimia ekstrak daun katuk (Sauropusandrogynus (L) Merr dengan GCMS. Warta Tumbuhan Obat Indonesia (3): 31-33.

Anonimous. 1992. Daftar Komposisi Bahan Makanan. Departemen Kesehatan. Bogor

Aziz, S. dan S. R. Muktingsih. 2006. Studi manfaat daun katuk (Sauropus androgynus). Cermin Dunia Kedokteran. Pusat Penelitian dan Pengembangan Farmasi. Badan Penelitian dan Pengembangan Kesehatan. Departemen Kesehatan Republik Indonesia. Jakarta No.151: 48-50.

Bregendahl, K. J., J. L. Sell and D. R. Zimmersnan. 2002. Effect of low proteindiets on growth performance and body composition of broiler chicks. Poultry Sci., 81: 11561167.

El-Hakim, Abd A. S., G. Cherian and M. N. Ali. 2009. Use of organic acid, herbs and their combination to improve the utilization of commercial low protein broiler diets. Int. J. Poultry Sci., 8 (1): 1420

Farahdiba, U. Santoso dan Kususiyah.2011. Pengaruh aras protein dan ragi tape terhadap kualitas karkas dan deposisi lemak pada ayam broiler. Jurnal Sain Peternakan Indonesia, 6: 47-54.

Hulshof, P.J.M., C.Xu, P. van de Bovenkamp, Muhilal, and C.E. West. 1997. Application of a validated method for the determination of provitamin A carotenoids in Indonesian food of different maturity and origin. $\mathbf{J}$ Agric food Chem 45: 1174-1179.

Pesti, G. M. 2009. Impact of dietary amino acid and crude protein level in broiler feeds on biological performance. J. appl. Poult. Res., 18: 477-486.

Santoso, U. 2001. Effect of Sauropus androgynus extract on the carcass quality of broiler chicks. Buletin Ilmu Peternakan dan Perikanan7: 22-28.

Santoso, U., Suharyanto and E. Handayani. 2001. Effects of Sauropus androgynus (Katuk) leaf extract on growth, fat accumulation and fecal microorganisms in broiler chickens. JITV 6 (4): 220226. 
Santoso, U., T. Suteky, Heryanto, dan Sunarti. 2002. Pengaruh cara pemberian ekstrak daun katuk (Sauropus androgynus) terhadap penampilan kualitas karkas ayam pedaging. JITV vol. 7 no. 3.

Saragih, D. T. R. 2005. Daun Katuk dalam Ransum Ayam Petelur dan Pengaruhnya terhadap Kandungan Vitamin A, Kolesterol Pada Telur Dan Karkas Serta Estrandiol Darah. Thesis. Program Pascasarjana. Institut Pertanian Bogor. Bogor. Subekti, S. 2003. Kualitas Telur dan Karkas Ayam Lokal yang Diberi Tepung Daun Katuk Dalam Ransum. Tesis. Bogor. Program Pascasarjana Institut Pertanian Bogor. Bogor.

Suprayogi, A. 2000. Studies on the Biological Effect of Sauropus androgynus (L.) Merr: Effect on Milk Production and the Possibilities of Induced Pulmonary Disorder in Lactating Sheep. Cuvillier Verlag Gottingen.

Swennen, Q., E. Decuypere and J. Buyse. 2007. Implications of dietary macronutrients for growth and metabolism in broiler chicken. World's Poultry Sci. 63: 541-556.

Wahju, J. 2004. Ilmu Nutrisi Unggas. Yogyakarta: Gadjah Mada University Press. 